\title{
GEOARCHAEOLOGICAL STUDIES ON ROMAN TIME HARBOUR SEDIMENTS IN COLOGNE - COMPARISON OF DIFFERENT OSL DATING TECHNIQUES
}

\author{
TOBIAS LAUER ${ }^{1}$, RAINER BONN ${ }^{2}$, MANFRED FRECHEN ${ }^{1}$, MAGRET C. FUCHS ${ }^{3}$, \\ MARCUS TRIER ${ }^{4}$ and SUMIKO TSUKAMOTO \\ ${ }^{1}$ Leibniz Institute for Applied Geophysics, Section 3: Geochronology and Isotope Hydrology, Stilleweg 2, 30655 Hannover, Germany \\ ${ }^{2}$ Geowissenschaftliche Dienstleistungen, Wasser Boden Landschaft, Zülpicher Str. 7, 50674 Köln, Germany \\ ${ }^{3}$ TU Bergakademie Freiberg, Geological Department, Gustav-Zeuner-Strasse 12, 09599 Freiberg, Germany \\ ${ }^{4}$ Römisch-Germanisches Museum / Archäologische Bodendenkmalpflege der Stadt Köln, 50667 Köln, Germany
}

Received 14 May $2010 \quad$ Accepted 10 November 2010

\begin{abstract}
Due to the construction of a new North-South subway in Cologne, Roman time harbour sediments were exposed and were sampled for luminescence dating. A very good independent age control was given by the precise knowledge of the chronology of Roman activity and by radiocarbon ages of charcoal samples. Hence, different methodological approaches within luminescence dating were applied for Holocene heterogeneously bleached fluvial samples and were compared to the known ages. For one sample, optically stimulated luminescence (OSL) dating was applied to coarsegrained quartz using a single aliquot regenerative-dose $(\mathrm{SAR})$ protocol. After $\mathrm{D}_{\mathrm{e}}$-measurements, different statistical approaches were tested (i.e. arithmetic mean, median, minimum age model, finite mixture model, leading edge method and the Fuchs and Lang approach). It is demonstrated that the Fuchs and Lang approach along with the leading edge method yielded the best matching OSL ages with respect to the known ages.

For the other sample which showed feldspar contamination within the quartz signal, the post-IR blue stimulated luminescence (double SAR protocol) was measured in three different ways to calculate the $\mathrm{D}_{\mathrm{e}}$-value: with continuous wave $(\mathrm{CW})$ stimulation with an IR-bleach at $50^{\circ} \mathrm{C}$ and at $225^{\circ} \mathrm{C}$ for $100 \mathrm{~s}$ prior to the OSL, and pulsed OSL (POSL). It was demonstrated that the IR-stimulation at $225^{\circ} \mathrm{C}$ has very good potential to remove the feldspar signal contribution as well as pulsed OSL, but the former might deplete parts of the quartz OSL signal.
\end{abstract}

Keywords: OSL, feldspar impurities, statistical models, Romans, Geoarchaeology.

\section{INTRODUCTION}

Luminescence dating is a tool to determine the deposition age of sediments. This provides important information for palaeolandscape reconstruction and also for archaeological studies, because optical dating of sedi-

Corresponding author: T. Lauer

e-mail: tobias.lauer@uni-leipzig.de ments can be very helpful to obtain a more precise chronological framework for human activity.

In this study we applied luminescence dating to two fluvial samples taken from Roman time harbour sediments in Cologne. The deposition age of these sediments correlates to the $1^{\text {st }}$ century $\mathrm{AD}$, as evidenced by Roman artefacts like broken ceramics and bricks. Independent age control was also given by three ${ }^{14} \mathrm{C}$ ages measured 
from charcoals. The purpose of this work is to apply luminescence dating to two samples of well-known age and to address the methodological problems related to incomplete bleaching and feldspar contamination of quartz.

It is known that fluvial deposits are often incompletely bleached (Wallinga, 2002; Jain et al., 2004; Arnold et al., 2007; Lauer et al., 2010) and therefore it is difficult to obtain correct ages for such deposits by optically stimulated luminescence dating. The dating of such material can be addressed by isolating those grains which have seen most sunlight by measuring large numbers of aliquots with few grains or even single grains (Wallinga, 2002; Thomas et al., 2005; Rodnight, 2008). The magnitude of scatter within dose distribution is taken into account as an indicator for insufficient bleaching. In this study we applied different statistical methods to a skewed equivalent dose distribution from one fluvial sample.

Furthermore, we tested various possibilities to minimize the feldspar signal contribution in contaminated quartz. Previous studies showed that feldspar inclusions within the quartz crystal lattice can strongly affect the luminescence signal (Wallinga et al., 2002; Lauer et al., 2010) and there are different possibilities to minimize the feldspar signal contribution. One method is to expose the feldspar contaminated quartz to infrared light prior to the detection of the quartz OSL signal (Wallinga et al., 2002; Kiyak and Erturaç, 2008). The pulsed OSL can be also used to separate quartz and feldspar OSL signals (Thomsen et al., 2008). In this study we tested two different temperatures $\left(50^{\circ} \mathrm{C}\right.$ and $\left.225^{\circ} \mathrm{C}\right)$ during the IR-exposure prior to the continuous wave $(\mathrm{CW})$ quartz OSL and also compared these results with that obtained by applying pulsed OSL.

\section{ARCHAEOLOGICAL BACKGROUND - CO- LOGNE DURING ROMAN TIMES}

During Roman times, the Rhine was the most important route of transport for people living in Cologne and in other places along the river (Dietmar and Trier, 2006). It is assumed that the first Romans settled in Cologne in the year 19/18 BC on the western bank of the river, later the colony "Colonia Claudia Ara Agrippinensium" (CCAA) was founded in the year $50 \mathrm{AD}$ (Dietmar and Trier, 2006). Fig. 1 shows that the Rhine was split up by an island that separated a subchannel from the main course of the river in Cologne at that time. Based on the excavated artefacts, this subchannel was already used as a Roman harbour in the early $1^{\text {st }}$ century $\mathrm{AD}$.

In the middle of the $2^{\text {nd }}$ century $\mathrm{AD}$, the harbour basin had to be given up due to long periods of little precipitation (Dietmar and Trier, 2006) causing a lower water table. After the abandonment of the harbour, the basin was rapidly silted up. Rapid sedimentation can be explained by the intensive agricultural use of lands around
Cologne leading to increased soil erosion and therefore higher fluvial sedimentation rates. Furthermore, the high sedimentation rate can be explained by the use of the harbour as a Roman time dump. A new harbour basin, located at the eastern side of the island, was then constructed for which dendrochronological data from pales yielded ages ranging from 160 to $180 \mathrm{AD}$ (Dietmar and Trier, 2006).

\section{SEDIMENTS AT THE SAMPLING SITE}

Sample SW-II was taken at a height of $39.30 \mathrm{~m}$ a.s.l. approximately $5 \mathrm{~m}$ away from sample SW-I (Fig. 2a). It represented a $20 \mathrm{~cm}$ thick calcareous sand layer showing a fine wavy lamination and rudimentarily climbing ripples. No archaeological artefacts were found in this layer. In the overlying layer, artefacts (broken ceramics, bricks and pieces of charcoal) were imbedded in a grey, deformed, silt-rich layer. The subjacent bed at the bottom of

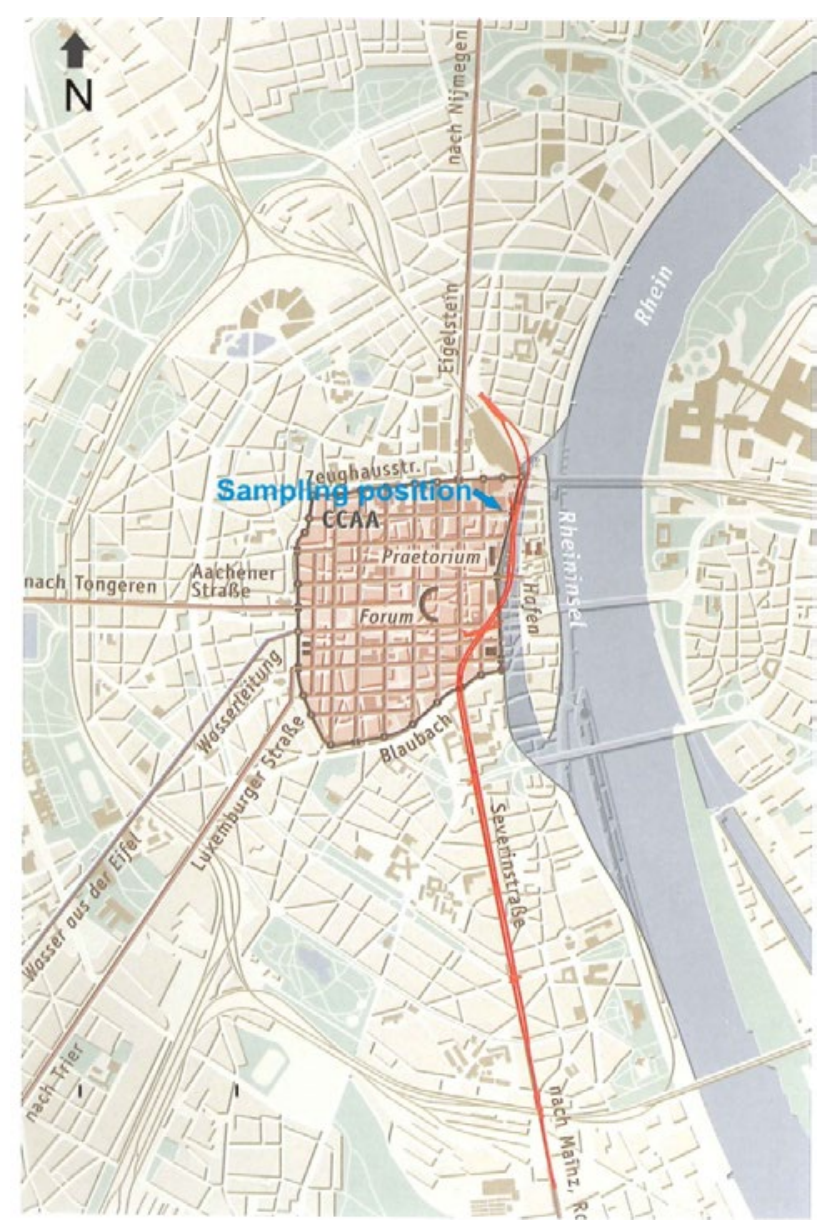

Fig. 1. Map of the Roman time city of Cologne after Dietmar \& Trier (2006). The red line marks the course of the new subway. The quarry Kurt Hackenberg Platz where samples were taken from is marked by the arrow. The map shows also the lateral side channel that could be used as a harbour during Roman times. 
the section also contained broken ceramics, bricks and pieces of charcoal, imbedded also in a grey deformed siltrich layer.

Sample SW-I (Fig. 2b) was taken at a height of 39.60 $\mathrm{m}$ a.s.l. from a $20-25 \mathrm{~cm}$ thick, calcareous and silt-rich sand layer showing a strongly deformed, irregular lamination. The layer contained fine humus and organic-rich particles, but did not contain artefacts except very small pieces of ceramics, bricks and charcoal. The sampled layer represented the top of a $0.5-0.75 \mathrm{~m}$ thick sediment sequence of light-grey and dark-grey, silt-rich fine sand. In the capping bed on the top of the section, artefacts, e.g. broken ceramics, bricks and pieces of charcoal were imbedded in a deformed, grey to dark-grey silt-rich layer. The subjacent bed at the base of the section was also a heterogeneous layer with broken ceramics, bricks and pieces of charcoal.

Grain size distribution and sedimentary structures suggest that both samples originated from flood deposit sequences. The sampled layers were composed of the mixture of fine grain suspended sediment and coarser bedload. Parts of the sampled sand in SW-I and SW-II were transported in a suspension, and the other parts were rolled and jumped over the bed of the side channel. A rapid sedimentation process at high flow velocity is most likely because both sampled layers contain almost no archaeological remains. It can be assumed that the deposition of these sediments refers to a single or a series of close events. The assumption that samples derived from flood deposit sequences is also supported by the fact that they were taken between 39.30 and $39.60 \mathrm{~m}$ a.s.l. This is close to the estimated mean water level of the River Rhine in Roman times which was at 39.0-41.0 m a.s.l. in the area of Cologne (Brunotte and Schulz, 2003; Bonn, 2006).
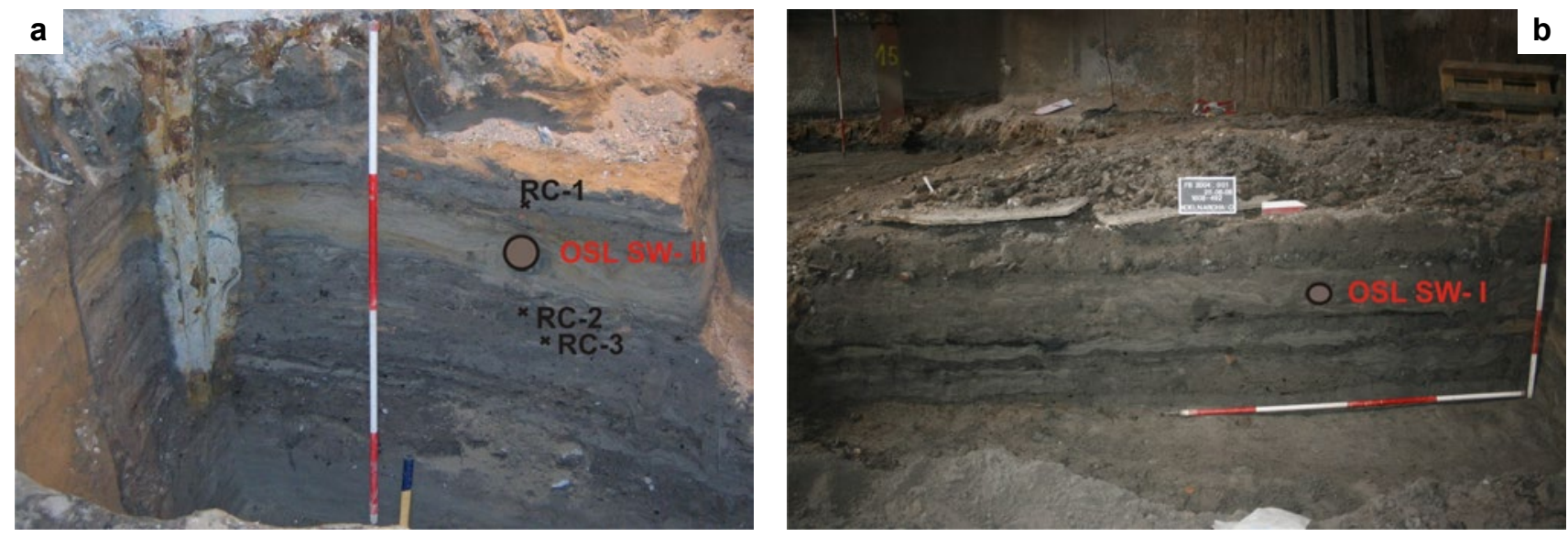

Fig. 2. Sampling points for OSL samples SW-II and SW-I. For SW-II material was taken from an intercalated fluvial sand layer. From the more heterogeneous material from above and below the sand layer, material for radiocarbon dating was taken (samples RC-1, RC-2, RC-3). Sample SW-I was taken in a distance of about 5 meters west from SW-II. The strong deformation structures around SW-I were assumed to have been caused by anthropogenic movements in shallow water. 


\section{Sample preparation for OSL dating}

To isolate the 100-200 $\mu \mathrm{m}$ quartz-rich fraction common procedures were applied including sieving of the dried material and chemical treatment with $10 \% \mathrm{HCl}$ for 30 minutes and $30 \%$ hydrogen peroxide for 12 hours to remove carbonates and organic matter, respectively. The quartz-rich fraction was isolated using heavy liquid (sodium polytungstate solution at 2.62 and $2.70 \mathrm{~g} / \mathrm{cm}^{3}$ ) and subsequently etched with $40 \%$ hydrofluoric acid (HF) for 60 minutes and re-sieved.

\section{Dose rate}

The material for gamma spectrometry was taken at exactly the same position as samples for luminescence dating. To determine the dose rate, the concentrations of ${ }^{238} \mathrm{U},{ }^{232} \mathrm{Th}$ and ${ }^{40} \mathrm{~K}$ (Aitken, 1998) were measured by high resolution gamma spectrometry using a high purity germanium detector. The in situ moisture content of the sediments could not be measured because the quarry was drained in the course of the subway construction. But it can be assumed that sediments were water saturated during most of the deposition time and therefore a water content of $18 \pm 6 \%$ was estimated. The dose rates of samples SW-I and SW-II were calculated to be at $2.0 \pm 0.2$ Gy/ka and $2.1 \pm 0.3 \mathrm{~Gy} / \mathrm{ka}$, respectively. The concentrations of radionuclides are quoted in Table 2.

\section{Equivalent dose measurements}

\section{Single aliquot regenerative dose measurements for sample SW-II}

For sample SW-II a SAR protocol was applied (Murray and Wintle, 2003) to determine the equivalent dose in coarse grained quartz. For measurements aliquots with a diameter of $3 \mathrm{~mm}$ were used. Prior to $\mathrm{D}_{\mathrm{e}}$ measurements, a dose recovery test was applied testing different preheat temperatures at a constant cutheat of $180^{\circ} \mathrm{C}$ and a hotbleach at $280^{\circ} \mathrm{C}$ at the end of every cycle (Fig. 3). The $\mathrm{D}_{\mathrm{e}}$ measurements were then conducted using a preheat at $220^{\circ} \mathrm{C}$ and a cutheat at $180^{\circ} \mathrm{C}$. The quartz signal was measured for $40 \mathrm{~s}$ at $125^{\circ} \mathrm{C}$. The hotbleach was inserted into the protocol for cleaning out remaining OSL signals. As quality criteria for further statistical analyses, all aliquots yielding a recycling ratio or an IR-depletion ratio of $> \pm 10 \%$ were rejected. All together 140 aliquots were measured, 80 aliquots successfully fulfilled the rejection criteria $(57 \%)$.

\section{Measurements of the post-IR blue-stimulated lumi- nescence}

Test measurements for sample SW-I indicated that the quartz OSL signal was strongly affected by feldspars which could not be removed by HF etching. Therefore different methodological approaches were tested (Table 3 ) to get a higher purity of the quartz OSL signal for this sample. To minimize the feldspar signal an IR-bleach either at $50^{\circ} \mathrm{C}$ or at $225^{\circ} \mathrm{C}$ was inserted to the measurement-cycles prior to the detection of the quartz signal (Wallinga et al., 2002; Zhang et al., 2007; Buylaert et al., 2009). Pulsed OSL (POSL; Thomsen et al., 2008) was also used; the LEDs were pulsed with $50 \mu$ s on-time and $100 \mu$ s off-time and the OSL signal was only recorded during the off-time. It has been reported that the luminescence lifetime for feldspar is shorter than for quartz, and thus if the signal is only recorded during the off-time of the LED stimulation, the OSL signal of feldspar contaminated samples should be dominated by quartz OSL signal (Denby et al., 2006; Thomsen et al., 2008).

Before measuring the equivalent dose, dose recovery (DR) tests were conducted applying the three different methodological approaches. The results show that all DR tests overestimate the given dose which was chosen close to the expected natural one. The pulsed measurements recovered the given dose with a ratio (measured/given dose) of $1.1 \pm 0.05$. The post-IR quartz CW OSL meas-

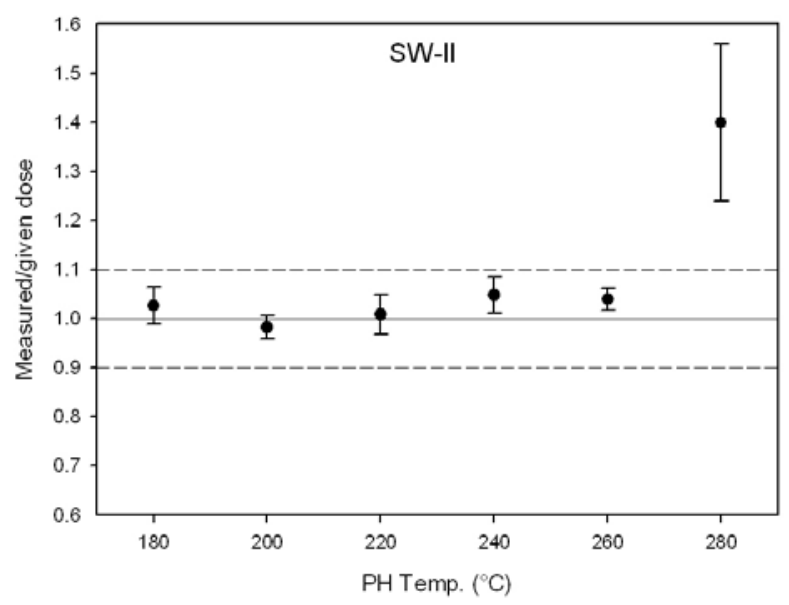

Fig. 3. Results from the dose recovery test applied to sample SW-II using different preheat temperatures. The cutheat was always at $180^{\circ} \mathrm{C}$, a hotbleach at $280^{\circ} \mathrm{C}$ was inserted into the protocol at the end of each SAR cycle. It can be seen, that a preheat at $220^{\circ} \mathrm{C}$ yielded the best dose recovery. For the measurements 4 aliquots were used at each preheat temperature.

Table 2. Nuclide concentrations and dose rates

\begin{tabular}{lccccc}
\hline Sample-Code & $\mathrm{K}(\%)$ & $\mathrm{Th}(\mathrm{ppm})$ & $\mathrm{U}(\mathrm{ppm})$ & Cosmic dose rate $(\mathrm{mG} / \mathrm{Ka})$ & Total dose rate (Gy/ka) \\
\hline SW-I & $1.47 \pm 0.02$ & $6.37 \pm 0.08$ & $1.97 \pm 0.04$ & 70 & $2.0 \pm 0.2$ \\
SW-II & $1.54 \pm 0.02$ & $6.50 \pm 0.06$ & $1.92 \pm 0.02$ & 70 & $2.1 \pm 0.3$ \\
\hline
\end{tabular}


Table 3. Different luminescence dating protocols applied to sample SW-I.

\begin{tabular}{|c|c|c|}
\hline Protocol I (CW) & Protocol II (CW) & Protocol III (POSL) \\
\hline $\begin{array}{l}\text { Give dose, } D_{i} \text { (beta irradiation using a }{ }^{90} \mathrm{Sr} /{ }^{00} \mathrm{Y} \\
\text { source) }\end{array}$ & Give dose, $D_{i}$ & Give dose, $D_{i}$ \\
\hline Preheat $\left(250^{\circ} \mathrm{C}\right)$ for $60 \mathrm{~s}$ & Preheat $\left(250^{\circ} \mathrm{C}\right)$ for $60 \mathrm{~s}$ & Preheat $\left(250^{\circ} \mathrm{C}\right)$ for $60 \mathrm{~s}$ \\
\hline IR-bleach (LED, $870 \mathrm{~nm}) @ 50^{\circ} \mathrm{C}$ for $100 \mathrm{~s}$ & IR-bleach @ 225 ${ }^{\circ} \mathrm{C}$ for $100 \mathrm{~s}$ & IR-bleach @ 50 C for $120 \mathrm{~s}$ \\
\hline $\begin{array}{l}\text { Detection of the post-IR CW blue-stimulated } \\
\text { quartz signal (stimulation }=40 \mathrm{~s} @ 125^{\circ} \mathrm{C} \text { ) }\end{array}$ & $\begin{array}{l}\text { Detection of the post-IR CW blue- } \\
\text { stimulated quartz signal }\end{array}$ & $\begin{array}{l}\text { Detection of the pulsed post-IR blue-stimulated quartz } \\
\text { signal (stimulation time }=120 \mathrm{~s} @ 125^{\circ} \mathrm{C} \text { ) }\end{array}$ \\
\hline Give test dose, $D_{t}$ & Give test dose, $D_{t}$ & Give test dose, $D_{t}$ \\
\hline Heat to $230^{\circ} \mathrm{C}$ & Heat to $230^{\circ} \mathrm{C}$ & Heat to $230^{\circ} \mathrm{C}$ \\
\hline IR bleach @ $50^{\circ} \mathrm{C}$ for $100 \mathrm{~s}$ & IR bleach @ 225ㅇ for $100 \mathrm{~s}$ & IR-bleach @ 50C for $120 \mathrm{~s}$ \\
\hline $\begin{array}{l}\text { Detection of the post-IR CW blue-stimulated } \\
\text { quartz signal }\end{array}$ & $\begin{array}{l}\text { Detection of the post-IR CW blue- } \\
\text { stimulated quartz signal }\end{array}$ & $\begin{array}{l}\text { Detection of the post-IR pulsed blue-stimulated quartz } \\
\text { signal }\end{array}$ \\
\hline Return to step 1 & Return to step 1 & Return to step 1 \\
\hline
\end{tabular}

urements recovered with a ratio of $1.08 \pm 0.04$ and $1.05 \pm 0.01$ after an IR exposure at $50^{\circ} \mathrm{C}$ and $225^{\circ} \mathrm{C}$, respectively. Hence, detecting the $\mathrm{CW}$ blue-stimulated quartz OSL after an IR exposure at $225^{\circ} \mathrm{C}$ yielded the best dose recovery.

$\mathrm{D}_{\mathrm{e}}$ measurements were then carried out by POSL and by measuring the $\mathrm{CW}$ blue-stimulated quartz signal after an IR-bleach at $50^{\circ} \mathrm{C}$ or at $225^{\circ} \mathrm{C}$. Preheat and cutheat were set to $260^{\circ} \mathrm{C}$ in each case. For measurements medium aliquots $(6 \mathrm{~mm})$ were used. It was not possible to use smaller aliquots due to the dim quartz OSL signal.

\section{RESULTS OF LUMINESCENCE DATING}

\section{Equivalent dose distribution of sample SW-II and statistical treatment}

Fig. 4 shows the distribution of obtained equivalent doses from sample SW-II. The skewed dose distribution is presumably due to incomplete bleaching i.e. insufficient sunlight exposure during fluvial transportation. The availability of independent age control provided the possibility of testing different statistical models:

1) Calculation of the median and the mean values from all obtained $\mathrm{D}_{\mathrm{e}}$ values which passed the rejection criteria

2) Applying a statistical approach proposed by Fuchs and Lang (2001) considering the fact that scattering of dose distribution is to a certain extent caused by methodological error and material specific variations. To estimate the best achievable precision regarding material-specific luminescence properties and measurement procedures, the relative standard deviation (coefficient of variation) of equivalent doses measured in response to a known laboratory dose against an applied known laboratory dose among dose recovery tests is seen to be appropriate. For the dose recovery test (Murray and Wintle, 2003), samples are first artificially bleached and then irradiated. Therefore all grains carry an equal dose and the selected measurement sequence for the sample should yield the same $D_{e}$ values (which is not really the case due

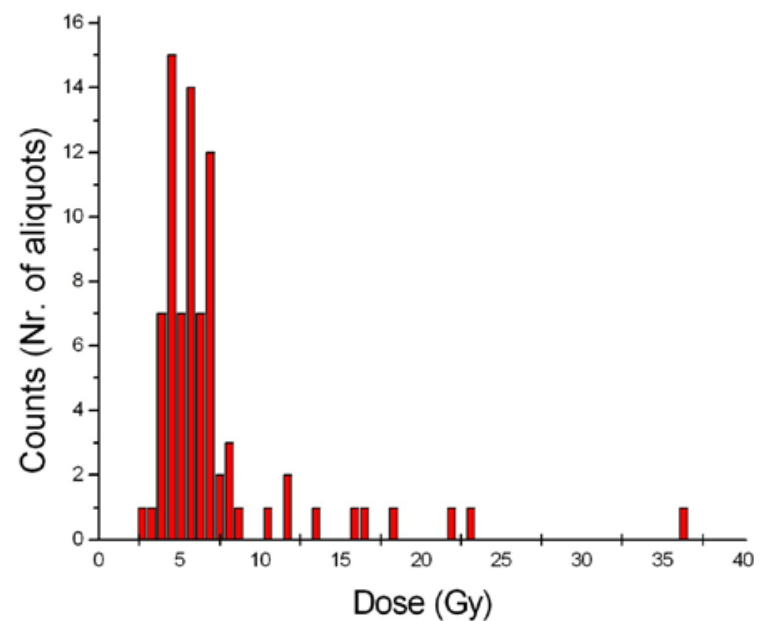

Fig. 4. Frequency distribution of measured equivalent doses from sample SW-II. For the measurements $3 \mathrm{~mm}$ sized aliquots were used. The class-width was defined by the median off all $D_{e}$-errors.

to methodological errors). When the scattering among recovered $D_{e}$ values is lower than scattering of $\mathrm{D}_{\mathrm{e}}$ values obtained by measurements of the "natural" $D_{e}$ values, incomplete bleaching is a very likely reason. Following the approach of Fuchs and Lang (2001) all $D_{e}$ values were first sorted from lowest to highest values. Starting with the two lowermost values arithmetic means were then calculated with increasing number of values until relative standard deviation exceeded the coefficient of variation determined from the dose recovery tests.

3) The leading edge method following Lepper and McKeever (2002) requires a frequency histogram with a class-width defined by the median value from all equivalent dose errors. A Gaussian function was used to fit the rising limb of the histogram with its peak representing the maximum frequency. All values which were equal or lower than the maximum of the Gaussian peak were included for calculations. 
4) The minimum age model (Galbraith and Laslett, 1993; Galbraith et al., 1999) excludes outliers among equivalent dose distribution in the higher range. It selects the lowermost population by fitting a truncated normal distribution to $\mathrm{D}_{\mathrm{e}}$ values.

5) The finite mixture model (Galbraith and Green, 1990) distinguishes between different components among an equivalent dose distribution (Rodnight et $a l$. ., 2006). Each component has to show an overdispersion of $10 \%$. The equivalent dose component representing the youngest equivalent dose population is then chosen for age calculations but this $\mathrm{D}_{\mathrm{e}}$ population should include at least $10 \%$ of the measured aliquots.

The $\mathrm{D}_{\mathrm{e}}$ values and the OSL age estimates are summarized in Table 4 and Fig. 5.

The OSL age estimates based on the mean and median equivalent dose values clearly overestimate the expected age because they include all or many of those $D_{e}$ values obtained from aliquots hosting numerous insufficiently bleached grains. The results given by the further statistical approaches are in better agreement with the age control as they reduce the influence of outliers, especially in the higher range, and focus on lower equivalent dose values.

It can be demonstrated that the results obtained by the approaches after Fuchs and Lang (2001) as well as the leading edge method (Lepper and McKeever, 2002) fit best to the age control given by the archaeological background (Fig. 5).

Also the result obtained by the minimum age model (MAM3) is still in agreement with the age control but only due to the expanded error bars. The central MAM3 value underestimates the expected age. This is most likely related to the fact, that the result is strongly affected by the lowermost equivalent dose values (see also Rodnight et al., 2006) and those might underestimate the true equivalent dose due to methodological error.

\section{Post IR-measurements on sample SW-I}

The presented decay curve of Fig. $\mathbf{6 c}$ indicates that after the IR-bleach at $50{ }^{\circ} \mathrm{C}$, a significant feldspar signal contribution is still left. Traps in feldspar, which are not bleached at $50^{\circ} \mathrm{C}$, are emptied only during the post-IR blue stimulation. If the IRSL signal is stimulated at $225^{\circ} \mathrm{C}$ (Fig. 6d) the purity of the post-IR blue stimulated quartz signal is much higher. This shows that the thermal assistance during IR-stimulation has positive effect for minimizing the feldspar signal in contaminated quartz.

The frequency histograms of equivalent doses obtained by the CW post-IR blue measurements are not skewed and show a distribution close to a Gaussian one (Figs. 7a and 7b) but it has to be taken into account that medium aliquots were used for measurements. Hence, the detection of incomplete bleaching is difficult as the true degree of scattering of doses could not be revealed. The mean $\mathrm{D}_{\mathrm{e}}$ values of sample SW-I are nevertheless general-
Table 4. $D_{e}$ values and the OSL age estimates from sample SW-Il using different statistical approaches. The standard deviation of sample SW-II (based on all counted $D_{e}$ values) is at $70 \%$. The recovered $D_{e}$ values from the $D R$ test have a standard deviation of only $8 \%$. The finite mixture model distinguished 6 components.

\begin{tabular}{lccc}
\hline $\begin{array}{l}\text { Statistical } \\
\text { model }\end{array}$ & $\begin{array}{c}\text { Equivalent } \\
\text { dose (Gy) }\end{array}$ & $\begin{array}{c}\text { OSL age } \\
\text { estimates } \\
\text { (years) }\end{array}$ & $\begin{array}{c}\text { Time span (in- } \\
\text { cluding error) } \\
\text { given by the OSL } \\
\text { data }\end{array}$ \\
\hline Mean & $7.1 \pm 0.56$ & $3460 \pm 350$ & $1800 \mathrm{BC}-1100 \mathrm{BC}$ \\
\hline Median & $5.8 \pm 0.56$ & $2830 \pm 320$ & $1140 \mathrm{BC}-500 \mathrm{BC}$ \\
\hline $\begin{array}{l}\text { Finite mixture } \\
\text { model }\end{array}$ & $4.4 \pm 0.2$ & $2140 \pm 150$ & $280 \mathrm{BC}-20 \mathrm{AD}$ \\
\hline $\begin{array}{l}\text { Fuchs and Lang } \\
\text { (2001) }\end{array}$ & $4.25 \pm 0.08$ & $2070 \pm 130$ & $190 \mathrm{BC}-70 \mathrm{AD}$ \\
\hline $\begin{array}{l}\text { "Leading edge" } \\
\text { after Lepper and }\end{array}$ & $4.11 \pm 0.05$ & $2000 \pm 130$ & $120 \mathrm{BC}-140 \mathrm{AD}$ \\
$\begin{array}{l}\text { McKeever } \\
\text { (2002) }\end{array}$ & & & \\
$\begin{array}{l}\text { Minimum age } \\
\text { model (MAM3) } \\
\text { after Galbraith et } \\
\text { al. (1999) }\end{array}$ & $3.47 \pm 1.2$ & $1690 \pm 590$ & $270 \mathrm{BC}-910 \mathrm{AD}$ \\
\hline
\end{tabular}

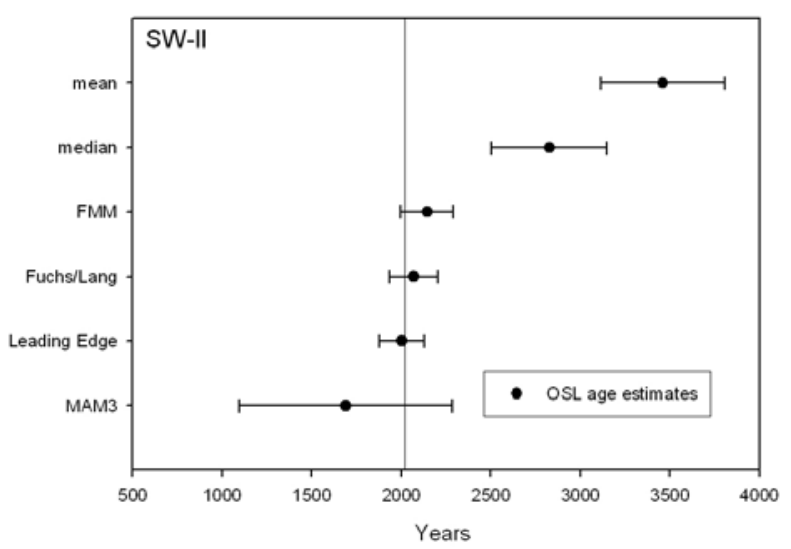

Fig. 5. OSL age estimates from sample SW-Il obtained by using different statistical approaches. The vertical line marks the beginning of the Roman settlement in the year 19/18 BC. The dated sediments cannot be older and should correlate to the 1st century $A D$.

ly lower than the mean $\mathrm{D}_{\mathrm{e}}$ value of sample SW-II (7.1 $\pm 0.56 \mathrm{~Gy})$, although the dose rates are almost equal. This indicates that the deposits from sample SW-I were better bleached.

The quartz OSL ages from sample SW-I were calculated by using the mean $D_{e}$ values obtained by the different measurement procedures. The age estimates range from $2220 \pm 170$ a (POSL) to $2500 \pm 190$ a (including the $\mathrm{CW}$ post-IR signal after an IR-bleach at $225^{\circ} \mathrm{C}$ ) and hence, all ages seem to overestimate the true age. It was demonstrated that measuring the quartz signal after an IR-bleach at $225^{\circ} \mathrm{C}$ yields the oldest age, hence this 

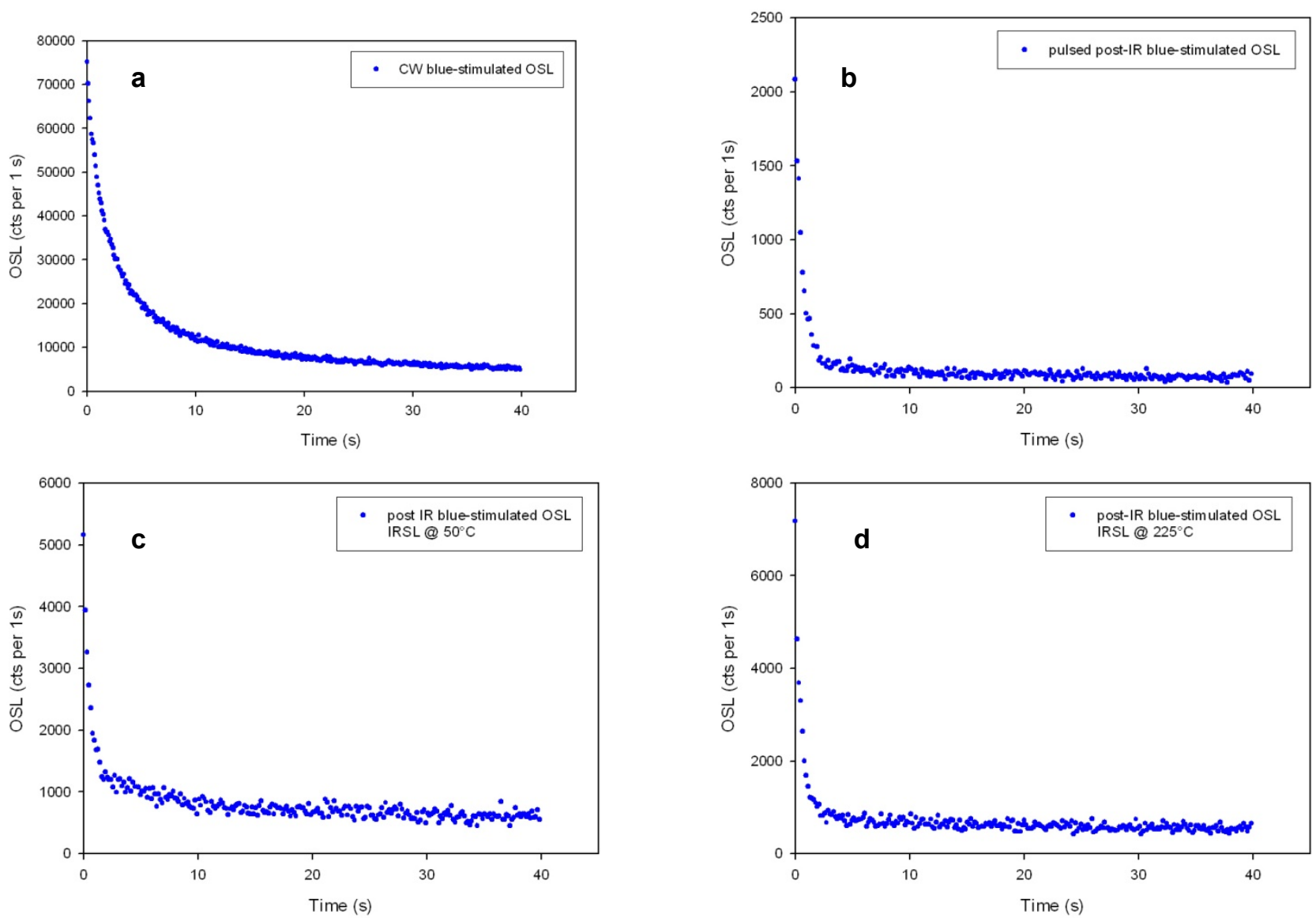

Fig. 6. Comparison of decay curves of the quartz OSL signal from sample SW-I. The CW quartz OSL signal is affected by feldspar impurities (a) what can be seen by the shape of the decay curve. The feldspar signal can be reduced by applying pulsed OSL (b) or by measuring the CW bluestimulated quartz OSL after exposing the material to infrared light for $100 \mathrm{~s}$ at $50^{\circ} \mathrm{C}$ and/or $225^{\circ} \mathrm{C}(c, d)$. A prior IR-bleach at $225^{\circ} \mathrm{C}$ or pulsed OSL yield the highest purity for the quartz signal in that case.
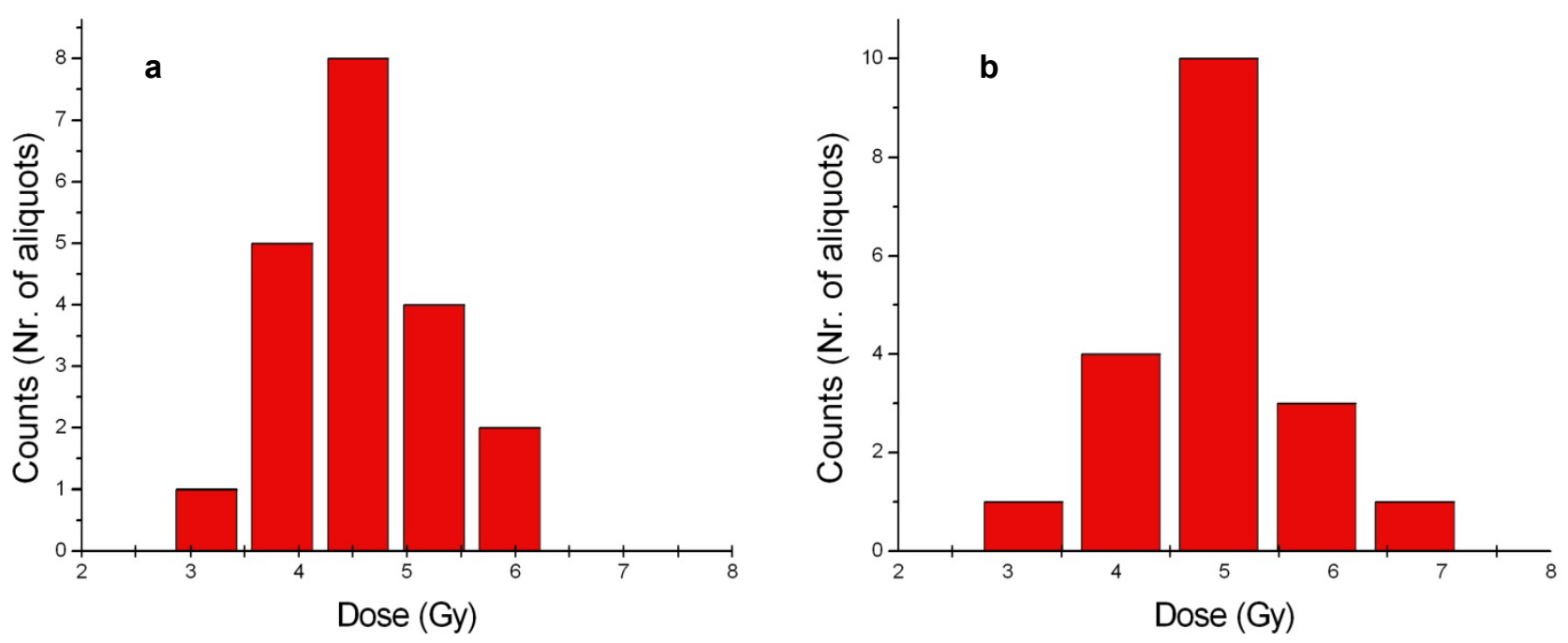

Fig. 7. Distribution of measured equivalent doses from sample $S W$-I based on the post-IR quartz signal measured after $I R$ exposure at $50^{\circ} \mathrm{C}($ a) and at $225^{\circ} \mathrm{C}$ (b). For measurements $6 \mathrm{~mm}$ sized aliquots had to be used due to the dim quartz OSL signal. The use of medium aliquots means that it is not possible to point out scatter among dose distribution in an effective way. 
approach results in the most significant age overestimation. The dose recovery test using the prior $225^{\circ} \mathrm{C}$ IRbleach yielded a measured to given dose of $1.05 \pm 0.01$ which was the lowermost of all tested protocols. Hence, the reason for this most significant age overestimation has to be elsewhere. It can be assumed that parts of the quartz OSL signal (especially fast component) were already depleted during the IR-bleaching step at $225^{\circ} \mathrm{C}$. If so, the effect of incomplete bleaching would be even more dominant.

The obtained $D_{e}$ values and different age estimates are presented in Table 5. Fig. 8 shows and compares all obtained $D_{e}$ values. $D_{e}$ values were also calculated by using the IRSL signal derived from the feldspar impurities (Table 5). The mean equivalent dose obtained from the IRSL signal measured at $50^{\circ} \mathrm{C}$ is lower than the corresponding $D_{e}$ value calculated from the post-IR quartz OSL signal. A similar relationship was observed between the equivalent doses obtained from the $225^{\circ} \mathrm{C}$ IRSL signal and the subsequent post-IR quartz OSL signal and this is most likely due to anomalous fading (Wintle, 1973). It should also be regarded that feldspar is more difficult to bleach (Wallinga, 2002) and therefore the

Table 5. $D_{e}$-values from sample SW-I obtained by applying different luminescence dating protocols (protocol I, II and III as described in Table 3). $D_{e}$-values were also calculated using the signal deriving from the prior IR-bleach $\left(50^{\circ} \mathrm{C}\right.$ and $\left.225^{\circ} \mathrm{C}\right)$.

\begin{tabular}{lccccc}
\hline & $\begin{array}{c}\text { Protocol } \\
\text { I }\end{array}$ & $\begin{array}{c}\text { Protocol } \\
\text { II }\end{array}$ & $\begin{array}{c}\text { Protocol } \\
\text { III }\end{array}$ & $\begin{array}{c}\text { IRSL @ } \\
50^{\circ} \mathbf{C}\end{array}$ & $\begin{array}{c}\text { IRSL @ } \\
\mathbf{2 2 5 ^ { \circ } \mathbf { C }}\end{array}$ \\
\hline $\begin{array}{l}\text { Demean } \\
\text { (Gy) }\end{array}$ & $4.6 \pm 0.2$ & $5.0 \pm 0.2$ & $4.4 \pm 0.2$ & $4.2 \pm 0.3$ & $4.2 \pm 0.2$ \\
\hline $\begin{array}{l}\text { Age } \\
\text { (years) }\end{array}$ & $2300 \pm 180$ & $2500 \pm 190$ & $2220 \pm 170$ & - & - \\
\hline
\end{tabular}

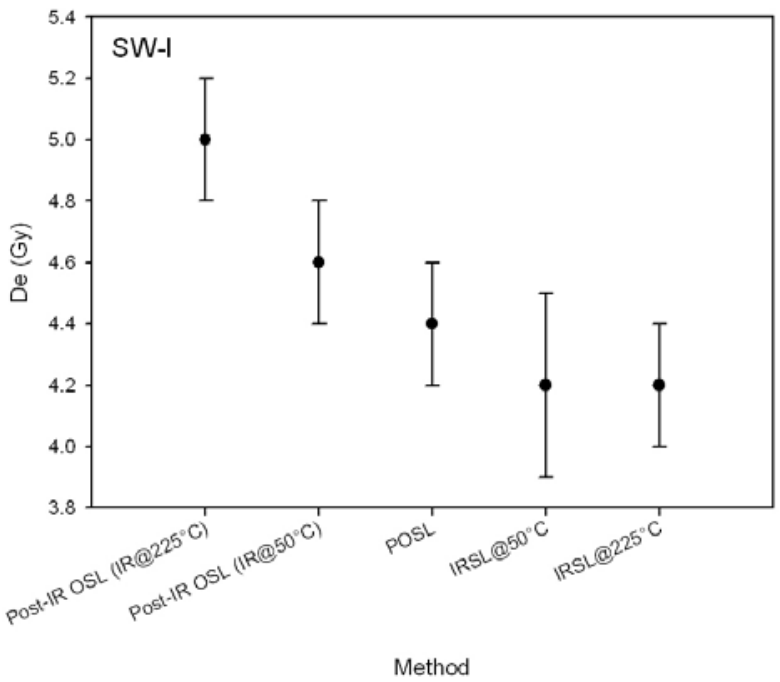

Fig. 8. Equivalent dose values from sample SW-I obtained by applying different luminescence dating protocols.
IRSL related equivalent doses should be higher if there is no fading.

\section{CONCLUSION}

Luminescence dating was applied to incompletelybleached fluvial samples from the Roman time harbour in Cologne. For both samples independent age control was available by artefacts and radiocarbon data. The luminescence ages from sample SW-II which were calculated by using the median and the mean $\mathrm{D}_{\mathrm{e}}$ values are at $2830 \pm 320$ years and $3460 \pm 350$ years, respectively. Hence, both ages overestimate the true age which should correspond to the time after the Romans started to use and fill up the harbour (beginning of the $1^{\text {st }}$ century AD).

The OSL age estimates from this sample which were calculated by using the statistical approach after Fuchs and Lang (2001) and Lepper and McKeever (2002) are at $2070 \pm 130$ and $2000 \pm 130$ years, respectively. Those ages correspond best with the information given by archaeologists and are also in good agreement with the radiocarbon ages.

The studies on sample SW-I concerning the minimization of the feldspar signal in quartz showed that the purity of the quartz OSL signal is higher if conducting the IR-stimulation at elevated temperatures $\left(225^{\circ} \mathrm{C}\right)$. Nevertheless it has to be taken into account that the IR-bleach at $225^{\circ} \mathrm{C}$ is most likely depleting parts of the quartz OSL signal.

\section{REFERENCES}

Aitken MJ, 1998. Introduction to Optical Dating. Oxford, Oxford University Press: Oxford: 280pp.

Arnold LJ, Bailey RM and Tucker GE, 2007. Statistical treatment of fluvial dose distributions from southern Colorado arroyo deposits. Quaternary Geochronology 2: 162-167, DOI 10.1016/j.quageo.2006.05.003.

Bonn R, 2006. Contribution to sedimentology. Excavations North-South City Railway Cologne. The Kurt-Hackenberg-Platz. 2nd record of the studies from October 2005 - April 2006 (Beitrag zur Sedimentologie. Ausgrabungen Nord-Süd-Stadtbahn Köln. Der KurtHackenberg-Platz. Zweiter Bericht zu den Untersuchungen von Oktober 2005 - April 2006); Köln (unpublished).

Brunotte E and Schulz W, 2003. About the localisation of a ship landing place based on geomorphological mapping at the Roman armada staging area at Köln-Alteburg (Zur Lokalisierung einer Schiffsanlagestelle beim römischen Flottenlager Köln-Alteburg aufgrund geomorphologischer Untersuchungen). Kölner Jahrbuch 36: 737743.

Buylaert JP, Murray AS, Thomsen KJ and Jain M, 2009. Testing the potential of an elevated temperature IRSL signal from K-feldspar. Radiation Measurements 44: 560-565, DOI 10.1016/j.radmeas.2009.02.007.

Denby PM, Bøtter-Jensen L, Murray AS, Thomsen KJ, and Moska P, 2006. Application of pulsed OSL to the separation of the luminescence components from a mixed quartz/feldspar sample. Radiation Measurements $\quad 41(7-8): \quad 774-779, \quad$ DOI 10.1016/j.radmeas.2006.05.017.

Dietmar C and Trier M, 2006. Mit der U-Bahn in die Römerzeit. Ein Handbuch zu den archäologischen Ausgrabungsstätten rund um den Bau der Nord-Süd Stadtbahn. Köln, Germany: 245 pp. 
Fuchs M and Lang A, 2001. OSL dating of coarse-grain fluvial quartz using single-aliquot protocols on sediments from NE Peloponnese, Greece. Quaternary Science Reviews 20: 783-787, DOI 10.1016/S0277-3791(00)00040-8.

Galbraith RF and Green PF, 1990. Estimating the component ages in a finite mixture. Nuclear Tracks and Radiation Measurements 17: 197-206, DOI 10.1016/1359-0189(90)90035-V.

Galbraith RF and Laslett G., 1993. Statistical models for mixed fission track ages. Radiation Measurements 21: 459-470, DOI 10.1016/1359-0189(93)90185-C.

Galbraith RF, Roberts RG, Laslett GM, Yoshida H and Olley JM, 1999. Optical dating of single and multiple grains of quartz from Jinmium Rock Shelter, northern Australia: Part 1, experimental design and statistical models. Archaeometry 41: 339-364, DOI 10.1111/j.1475-4754.1999.tb00987.x.

Jain M, Murray AS and Bötter-Jensen L, 2004. Optically stimulated luminescence dating: How significant is incomplete bleaching in fluvial environments. Quaternaire 15: 143-157.

Kiyak NG and Erturaç MK, 2008. Luminescence dating of feldspar contaminated quartz from fluvial terrace sediments. Geochronometria 30: 55-60, DOI 10.2478/v10003-008-0007-8.

Lauer T, Frechen M, Hoselmann C and Tsukamoto S, 2010. Fluvial aggradation phases in the Upper Rhine Graben - New insights by quartz OSL dating. Proceedings of Geologists' Association. 121: 154-161, DOI 10.1016/j.pgeola.2009.10.006.

Lepper K and McKeever SWS, 2002. An objective methodology for dose distribution analysis. Radiation Protection Dosimetry 101: 349-352.

Murray AS and Wintle AG, 2003. The single aliquot regenerative dose protocol: potential for improvements in reliability. Radiation
Measurements 37: 377-381, DOI 10.1016/S1350-4487(03)000532.

Rodnight H, Duller GAT Wintle AG and Tooth S, 2006. Assessing the reproducibility and accuracy of optical dating of fluvial deposits. Quaternary Geochronology 1: 109-120, DOI 10.1016/j.quageo.2006.05.017.

Rodnight H, 2008. How many equivalent dose values are needed to obtain a reproducible distribution? Ancient TL 26: 3-10.

Thomas PJ, Jain M, Juyal N and Singhvi AK, 2005. Comparison of single-grain and small-aliquot OSL dose estimates in $<3000$ years old river sediments from South India. Radiation Measurements 39: 457-469, DOI 10.1016/j.radmeas.2004.07.005.

Thomsen KJ, Jain M, Murray AS, Denby PM, Roy N and Bøtter-Jensen L, 2008. Minimizing feldspar OSL contamination in quartz UVOSL using pulsed blue stimulation. Radiation Measurements 43: 752-757, DOI 10.1016/j.radmeas.2008.01.020.

Wallinga J, 2002. Optically stimulated luminescence dating of fluvial deposits: a review. Boreas 31: 303-322, DOI 10.1111/j.15023885.2002.tb01076.x.

Wallinga J, Murray AS and Bøtter-Jensen L, 2002. Measurement of the dose in quartz in the presence of feldspar contamination. Radiation Protection Dosimetry 101: 367-370.

Wintle AG, 1973. Anomalous fading of thermoluminescence in mineral samples. Nature 245: 143-144, DOI 10.1038/245143a0.

Zhang JF, Fan CH, Wang H and Zhou LP, 2007. Chronology of an oyster reef on the coast of Bohai Bay, China: Constraints from optical dating using different luminescence signals from fine quartz and polymineral fine grains of coastal sediments. Quaternary Geochronology 2: 71-76, DOI 10.1016/j.quageo.2006.05.027. 